\title{
EFFECT OF MANAGEMENT PRACTICES ON MYCORRHIZAL INFECTION, GROWTH AND DRY MATTER PARTITIONING IN FIELD-GROWN BEAN'
}

\author{
ANTONIO ALBERTO ROCHA OLIVEIRA ${ }^{2}$ and FRANCIS EDWARD SANDERS ${ }^{3}$
}

\begin{abstract}
The experiment was carried out on unsterilized field soil with low phosphorus availability with the objective of examining the effect of cultural practices on mycorrhizal colonization and growth of common bean. The treatments were: three pre-crops (maize, wheat and fallow) followed by three soil management practices ("ploughing", mulching and bare fallow without "ploughing" during the winter months). After the cultural practices, Phaseolus vulgaris cv. Canadian Wonder was grown in this soil. Fallowing and soil disturbance reduced natural soil infectivity. Mycorrhizal infection of the bean roots occurred more rapidly in the recently cropped soil than in the fallow soil. Prior cropping with a strongly mycorrhizal plant (maize) increased infectivity even further.
\end{abstract}

Index terms: Phaseolus vulgaris, arbuscular mycorrhizal fungi, soil management practices, crop rotation.

EFEITO DE PRÁTICAS CULTURAIS SOBRE A INFECÇÃO MICORRÍZICA,
CRESCIMENTO E PARTIÇÃO DA MATÉRIA SECA DE FEIJÃO-VAGEM

RESUMO - O experimento foi realizado em solo não-esterilizado com baixo teor de fósforo. Os tratamentos foram: três pré-cultivos (milho, trigo e solo nu), seguidos por três manejos do solo (distúrbio mecânico do solo, cobertura morta e solo nu sem distúrbio no inverno). No ano seguinte à aplicação dos tratamentos, a área experimental foi semeada com Phaseolus vulgaris cv. Canadian Wonder. Os tratamentos com solo nu e o submetido a distúrbio mecânico exibiram as menores densidades de esporos de fungos micorrízicos e reduzida infecção radicular do feijoeiro. A infecção micorrízica foi maior nas parcelas anteriormente cultivadas com cereais, especialmente no pré-cultivo com milho.

Termos para indexação: Phaseolus vulgaris, fungos micorrízicos arbusculares, manejo do solo, rotação de cultura.

\section{INTRODUCTION}

Field trials with arbuscular mycorrhizas are still beset with the problems of large scale production of inoculum, its storage and application to the crop. An alternative approach is to manipulate indigenous arbuscular mycorrhizal (AM) fungi by cultural practices or by the use of soil amendments that increase the effectiveness of the natural inocula (Daft, 1992). As an example of the manipulation of natural AM

\footnotetext{
${ }^{1}$ Accepted for publication on July 7, 1998.

2 Agronomist, Ph.D., Embrapa-Centro Nacional de Pesquisa de Mandioca e Fruticultura Tropical (CNPMF), Caixa Postal 007, CEP 44380-000 Cruz das Almas, BA. E-mail: alberto@cnpmf.embrapa.br

3 Agronomist., Ph.D., University of Leeds, Department of Pure and Applied Biology, Leeds LS2 9JT, United Kingdom.
}

endophytes, pre-cropping has been used to enhance mycorrhizal inoculum potential (Dodd et al., 1990a, 1990b; Ellis et al., 1992). Enhancement of mycorrhiza inoculum potential by a given pre-crop may improve the mycorrhizal activity of a subsequent crop in the rotation (Barea et al., 1993). This is generally supposed to be because the fungi develop and sporulate most on the roots of those plant species which are most susceptible to mycorrhizal infection. Susceptible crops which, in the rotation, follow nonhost plants (or plants which develop little mycorrhizal infection) may carry less infection than they would following a strongly mycorrhizal crop (Ocampo \& Hayman, 1981). Not surprisingly, Black \& Tinker (1977) found fewer spores in soil kept fallow than in adjacent soil cropped with barley.

AM fungi simultaneously occupy two different environments (the soil and roots) and their ecophysi- 
ology is influenced by both. It is likely, therefore, that agricultural practices, leading to changed soil conditions, greatly modify the inoculum potential of these fungi. Their infectivity in soil can be severely reduced by soil disturbance (Anderson et al., 1987; Jasper et al., 1989a, 1989b; Bentivenga \& Hetrick, 1992). Soil disturbance in maize (Zea mays L.) plots which had been untilled for a long period was first reported to result in reduction of AM colonization and $\mathrm{P}$ absorption in young maize plants (O’Halloran et al., 1986). McGonigle et al. (1990) observed, in both a growth chamber and a field study, that $\mathrm{P}$ absorption by young maize plants increased progressively as the degree of soil disturbance decreased from severe disturbance to no disturbance. To ensure that the mycorrhizal infectivity is maintained, spores or other propagules should be robust enough to survive disturbance, since the ability of these structures to survive and to initiate new mycorrhizal infections may be extremely important for long term survival of the fungi. Janos (1987), working in the tropics, claimed that immediate plant responses to mycorrhiza may be disfavored following severe soil disturbance.

The field experiment described in this work examined the effect of some agronomic practices on mycorrhizal colonization and growth of common bean.

\section{MATERIAL AND METHODS}

The experiment lasted from June 1993 to August 1994 and was done on a sandy clay loam soil at the Field Station of the University of Leeds, England. Analyses of the soil revealed an initial $\mathrm{pH}$ of 7-7.4, low phosphorus availability $\left(10 \mathrm{mg} \mathrm{kg}^{-1}\right), 11.7 \mathrm{mg} \mathrm{kg}^{-1} \mathrm{NH}_{4}-\mathrm{N}$ and $14.0 \mathrm{mg} \mathrm{kg}^{-1} \mathrm{NO}_{3}-\mathrm{N}$ (Inglaterra, 1986).

The site was divided into 36 plots of $6.75 \mathrm{~m}^{2}$ separated by $0.50 \mathrm{~m}$ paths. A randomized block design consisting of nine treatments with four replications was used. The treatments were: three pre-crops (maize, wheat and fallow) followed by three soil management practices ("ploughing", mulching or bare fallow during the winter months). Factorial analysis was not required because the sought effects of cultural practices on the subsequent test crop (bean) were measured as individual treatments.

On June 8, 1993, maize (Zea mays L.) cv. Pursan 3605, was sown at $25 \mathrm{~cm}$ by $20 \mathrm{~cm}$ spacing. On the same date, wheat (Triticum aestivum L.), mixed varieties, was sown at approximately 100 seeds $\mathrm{m}^{-2}$.

Following removal of all aboveground plant biomass in the fall (November 10, 1993), the plots were "ploughed" (hand digging with a spade), covered with mulch or kept bare. Surface mulching was accomplished by covering the soil with polyethylene sheet and a $25 \mathrm{~cm}$ layer of wheat straw. Bare paths $(0.5 \mathrm{~m}$ wide) bordered by shallow trenches were designed to minimize the migration of the mycorrhizal fungal propagules from pre-cropped to fallowed plots.

Soil temperatures were recorded throughout the winter using thermistor probes buried in the centre of the plots.

Plots were sampled to estimate spore density on the first occasion immediately before the pre-crop was harvested (October 28, 1993) and on a second occasion in the following spring (March 9, 1994) before the test bean crop was sown. Samples were collected from 0 to $20 \mathrm{~cm}$ depth with a coring auger from all four replicate plots of each treatment. The spores of indigenous AM fungi were then extracted using modified differential water-sucrose centrifugation (Gerdemann \& Nicolson, 1963; Jenkins, 1964).

Phaseolus vulgaris cv. Canadian Wonder was sown with a spacing of $45 \mathrm{~cm}$ between rows and $15 \mathrm{~cm}$ between plants in all the 36 plots. Two seeds were placed in each position and later thinned to one plant.

There were two harvests (July 7 and August 1, 1994). Four entire plants from each plot were excavated at first harvest (14 days after seedling emergence - dae). At the second harvest ( 39 dae), eight plants were harvested but roots were not collected. At each harvest time, shoots and roots (when collected) were dried at $70^{\circ} \mathrm{C}$ for 72 hours to determine the dry weight. Leaf area and root length density were also determined.

On three occasions during the growth period, root samples were collected, washed free of soil, cleared and stained by the standard technique (Phillips \& Hayman, 1970) and the percent of root length with AM infection was measured (Giovannetti \& Mosse, 1980).

Fertilizers (except phosphorus) and pesticides were applied at rates recommended for optimum crop production (White \& Izquierdo, 1991).

\section{RESULTS AND DISCUSSION}

\section{Spore density}

After harvesting the cereals in 1993, before autumn ploughing and mulching, spore density showed differences related to the pre-cropping treatment 
(Fig. 1). Populations of indigenous AM fungi were lower in fallow plot than in plots cropped with maize or wheat. The highest number of spores were found in maize plots.

During the winter there was a general decline in spore densities, which was greatest when soil was ploughed or kept bare. Fallowing followed by autumn ploughing resulted in a severe decrease of spore population. Numbers in mulched soil, previously cropped with maize, appeared not to decline at all.

\section{Soil temperature}

The winter of 1993-1994 was relatively cold, with soil temperatures at $15 \mathrm{~cm}$ depth remaining below $5^{\circ} \mathrm{C}$ for the months of January and February

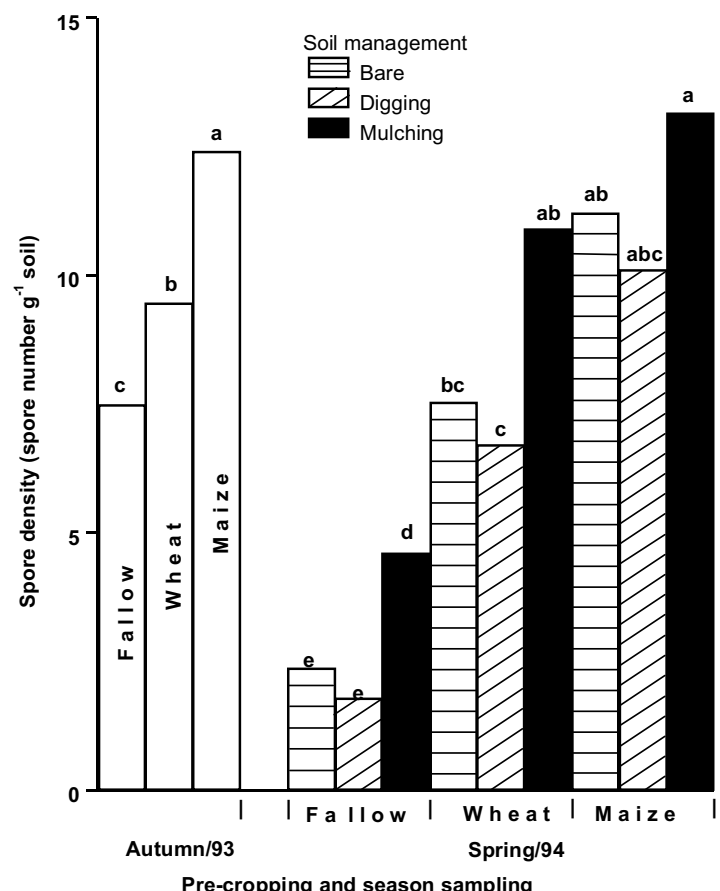

FIG. 1. AM spore density in field soil as influenced by management practices. Sampling dates: Oct. 28/93 (autumn) and Mar. 9/94 (spring). Within each sampling date, bars with different letters indicate significantly different means $(P=0.05)$. Analysis of variance carried out on $\log _{10}(\mathbf{n}+0.1)$-transformed data; nontransformed means presented.
(Fig. 2). During this period an ice layer formed and was maintained in the uncovered soil resulting of soil water in excess of field capacity and subzero air temperatures. Soil temperatures in mulched plots remained significantly higher than in uncovered plots during January and February.

\section{Mycorrhizal infection}

Mycorrhizal infection was found in all treatments of this experiment at all sample dates. There was a significant effect of pre-cropping on the arc sinetransformed data for AM infection (\%). Fig. 3 shows the untransformed data. In all cases, AM infection increased with time but bean plants with preceding fallow had the lowest mycorrhizal infection at all sampling times. The maximum infection was in plots previously cropped with maize.

The percentage of infection by these indigenous AM fungi was also influenced by soil management

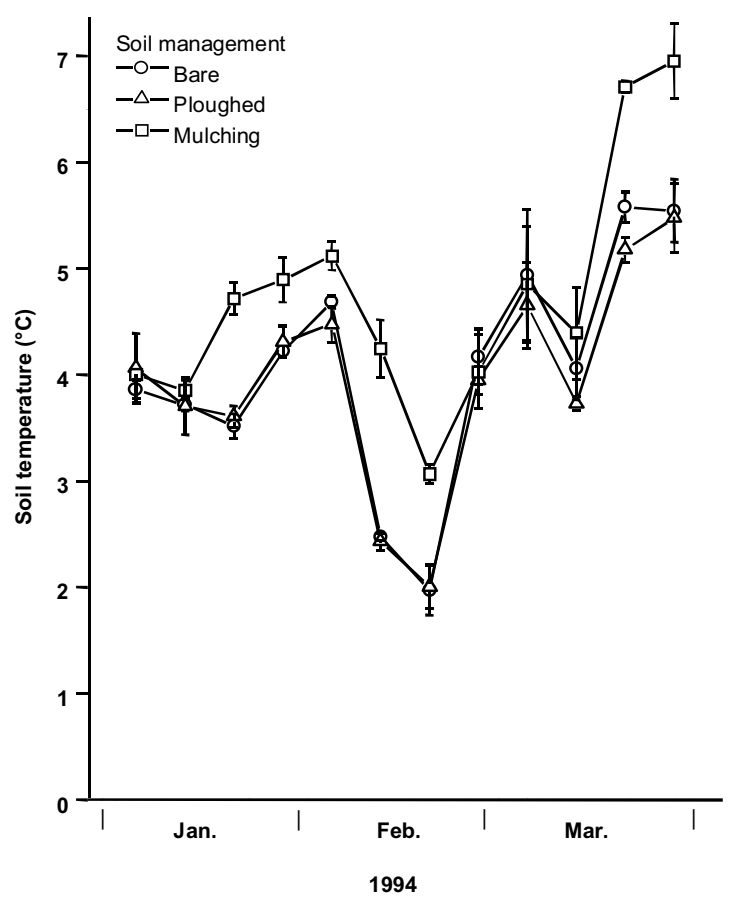

FIG. 2. Soil temperatures at a depth of $\mathbf{1 5} \mathrm{cm}$ as influenced by management practices. Vertical bars represent standard error of the means. 
practices following pre-cropping. At final harvest, plots cropped with wheat and subsequently ploughed or left bare had lower levels of mycorrhizal infection than mulched plots.

There was a significant relationship between spore densities before planting and mycorrhizal infection of bean at the final harvest. Significant model could be fitted in these parameters:

$$
y=\frac{-141.01}{1+e^{(x-0.68) / 3.89}}+94.02 ; r=0.84 ; p=0.01
$$

\section{Plant growth}

Table 1 summarizes the effect of previous cultural practices on growth of the subsequent bean crop.

Root, stem and leaf dry weights of the bean test crop were significantly higher after maize and lower after fallow compared with after wheat, for all sampling dates. Pod dry weights also tended to be lower after fallow than after maize or wheat.

Significant differences were also observed in root length density and leaf area. Root length density was higher in plots that were previously cropped with

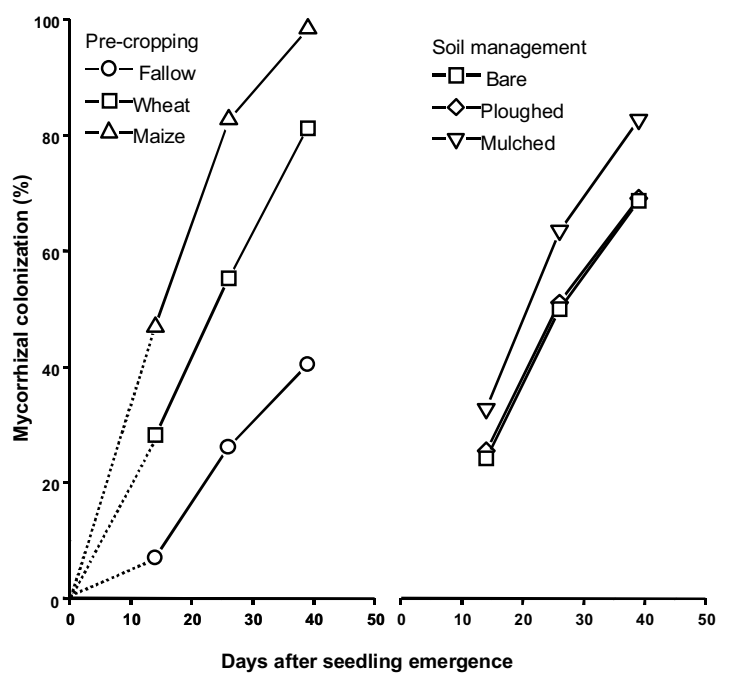

FIG. 3. Mycorrhizal colonization of Phaseolus vulgaris cv. Canadian Wonder as influenced by soil management practices.

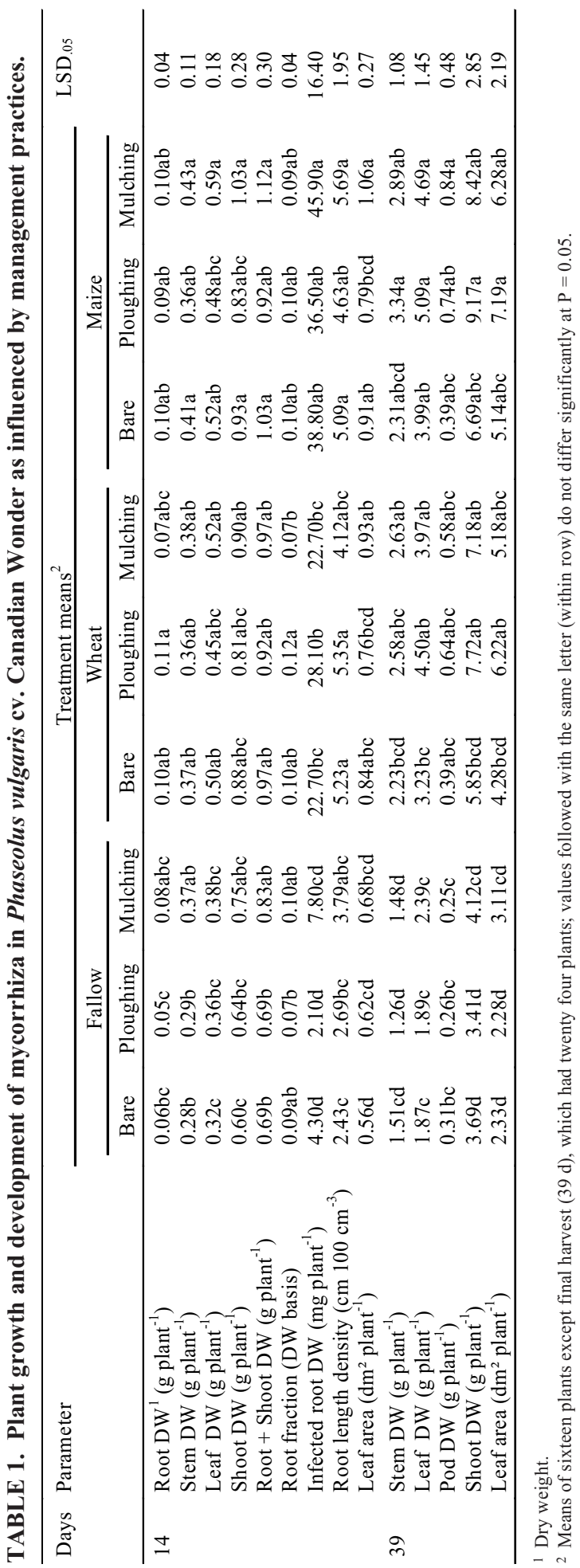

Pesq. agropec. bras., Brasília, v.34, n.7, p.1247-1254, jul. 1999 
cereals. The lowest leaf areas were recorded for fallow and the highest for maize treatments.

At the first harvest, analysis of the ratio of belowground to aboveground biomass revealed no obvious trend in root fraction among treatments.

The changes in spore density that occurred as a result of the different pre-crops were reflected in the levels of mycorrhizal infection in the subsequent bean crop. There is clearly a curvilinear relationship between spore density at sowing and the infection percentage of the beans at 39 dae (Fig. 4). The much faster build-up of AM infection in bean after maize compared to wheat or fallow strongly suggests increased inoculum or increased infectivity of the indigenous AM fungi, or both. Harinikumar \& Bagyaraj (1989) showed that different crops alter the production of infective propagules over three growing seasons. The results also agree with reports by Struble \& Skipper (1988) and Simpson \& Daft (1990), who described an effect on both spore density and AM development.

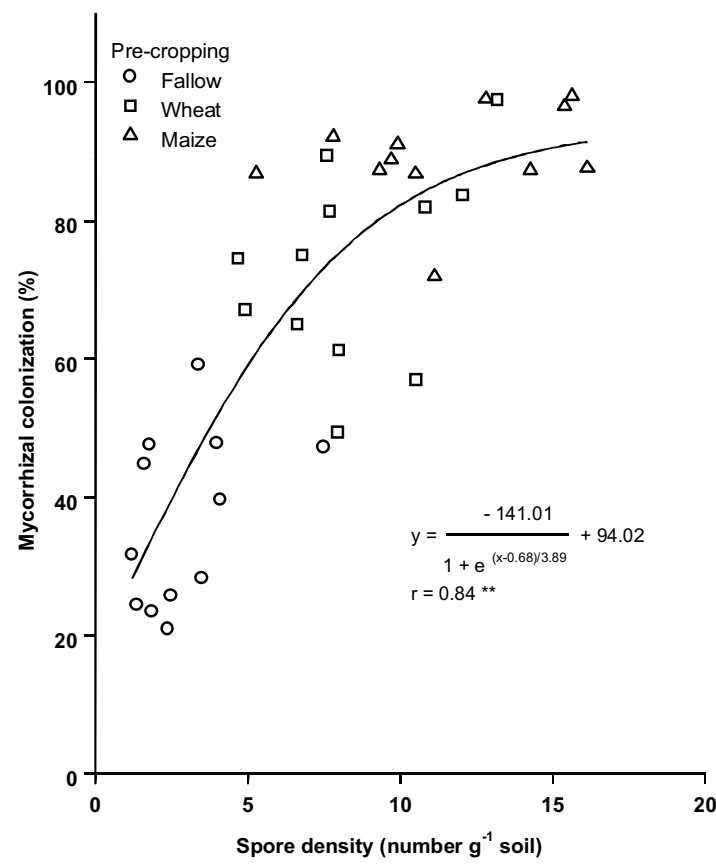

FIG. 4. Relationship between mycorrhizal colonization of Phaseolus vulgaris cv. Canadian Wonder (at 39 days after seedling emergence) and spore density of AM fungi before sowing.
Most of the spores in fallow soil probably came from the previous year's crop. Sparse sporulation in fallowed soil resulted in low inoculum density at the beginning of the subsequent growing season and this was clearly sufficiently low to influence mycorrhizal establishment in the beans. Infection levels never attained those in precropped soils. The conventional practice of the soil lying bare from autumn through to a spring sowing may be detrimental to AM fungi. Spore densities may drop drastically during longer fallow periods, as has been reported for arable crops (Black \& Tinker, 1977; McGraw \& Hendrix, 1986). In vertisolic soils of Northern Australia many crops grow poorly after long fallows (>12 months). This phenomenon is known as long fallow disorder. This disorder may result, in part, from a decline in propagules of AM fungi during fallow with consequently poor mycorrhizal colonization of the next crop (Thompson, 1987).

Comparisons between the cereals showed that spore density was lower after wheat, probably due to the lower density of infectable roots, than after maize. The data indicate that, although both are Graminaceae, there may be a lower infection potential in wheat roots than in maize. This observation is in agreement with previous findings that maize usually supports higher mycorrhizal populations than wheat (Hayman, 1987).

The inoculum carry-over from maize increased shoot dry weight at 39 days after seedling emergence by an average of $17 \%$ and $116 \%$ more than that from wheat or fallow. Irrespective of soil management practice after precropping, all the bean plants grown in maize-plots produced greater pod yield than the plants grown in fallowed soil. That decreased growth of the previous crop depressed the native mycorrhizal population was reported by Hayman (1982) who worked with a crop rotation of maize after oilseed rape (a non-mycorrhizal plant). Maize after rape grew poorly with marked P-deficiency symptoms, whereas maize after maize grew well. Root samples collected in early summer showed $12 \%$ mycorrhizal infection in maize after rape, in contrast to $71 \%$ in maize after maize.

Ploughing the plots reduced AM infection of the subsequent crop. Soil disruption as previously mentioned may be responsible for this. Differences in 
spore numbers among tillage regimes have been reported (Kruckelmann, 1975) and it is well accepted that minimal cultivation or zero-tillage favours high levels of mycorrhizal infection (Barea et al., 1993). An undisrupted mycelial network appears to be an important component of the inoculum potential of an undisturbed soil and its destruction may be responsible for much of the effect of soil disturbance on mycorrhizal colonization (Jasper et al., 1989a; Evans \& Miller, 1990; McGonigle \& Miller, 1993a, 1993b).

Overwintering losses of spores seemed to be affected by soil temperatures, so that the percentage loss was greatest when soil was left uncovered and subjected to cold conditions prevalent in the period. The straw mulch effectively insulated the soil from sizeable heat loss. Mulching undisturbed soil preceding a mycotrophic crop such as bean may be valuable for keeping inoculum levels high and hence ensuring rapid infection of the crop.

Spore counts were high in the autumn prior to bean sowing but the soil disturbance associated with cold conditions of the winter resulted in decreased spore population, although the effects were less pronounced in precropped soils. This supports the hypothesis that the overall infectivity of AM fungi is less affected by soil disturbance in soils containing high number of spores and mycorrhizal roots (Jasper et al., 1991). These factors indicated that the initial concentration of the infective propagules, in this case spores, might affect the temporary survival of the endophytes in the absence of the host. Survival in the field involves not only spores, but also fragments, hyphae and living mycorrhizal roots and this experiment has not examined their response to cultural practices. Many species of AM fungi are known to also regrow from root fragments that are fresh (Bierman \& Linderman, 1983), though little is known about the time required for the fragments to initiate colonization except that it can be shorter than four weeks (Tommerup \& Abbott, 1981). However, the longer the inoculum is kept from a host the more likely is infection to initiate from a spore, since spores can survive longer in the absence of a host than other propagules (Smith, 1980).

This study supports the theory that a strongly mycotrophic crop can be a convenient means of building up and revitalizing an indigenous AM population so that mycorrhizal responses in subsequent crops may be increased (Hayman, 1987; Dodd et al., 1990a, 1990b; Ellis et al., 1992), which is particularly important for agriculture in tropical soils where crop rotation is a normal practice.

\section{CONCLUSIONS}

1. Under these conditions the most serious events which reduce natural soil infectivity of arbuscular mycorrhizal fungi are fallowing and soil disturbance.

2. Mycorrhizal colonization of the bean roots occurs more rapidly in the recently cropped soil than in the fallow soil.

\section{REFERENCES}

ANDERSON, E.L.; MILLNER, P.D.; KUNISHI, H.M. Maize root length density and mycorrhizal infection as influenced by tillage and soil phosphorus. Journal of Plant Nutrition, New York, v.10, p.13491356, 1987.

BAREA, J.M.; AZCÓN, R.; AZCÓN-AGUILAR, C. Mycorrhiza and crops. Advance in Plant Pathology, London, v.9, p.167-189, 1993.

BENTIVENGA, S.P.; HETRICK, B.A.D. The effect of prairie management practices on mycorrhizal symbiosis. Mycologia, New York, v.84, p.522-527, 1992.

BIERMANN, B.; LINDERMAN, R.G. Use of vesiculararbuscular mycorrhizal roots, intraradical vesicles and extraradical vesicles as inoculum. New Phytologist, Cambridge, v.95, p.97-105, 1983.

BLACK, R.; TINKER, P.B. Interaction between effects of vesicular-arbuscular mycorrhiza and fertilizer phosphorus on yields of potatoes. Nature, London, v.267, p.510-511, 1977.

DAFT, M.J. Use of mycorrhizas in agriculture: Problems and prospects. In: READ, D.J.; LEWIS, D.H.; FITTER, A.H.; ALEXANDER, I.J. (Eds.). Mycorrhizas in ecossystems. Wallingford: $C A B$ International, 1992. p.198-201.

DODD, J.C.; ARIAS, I.; KOOMEN, I.; HAYMAN, D.S. The management of populations of vesiculararbuscular mycorrhizal fungi in acid-infertile soils 
of a savanna ecosystem. I. The effect of pre-cropping and inoculation with VAM-fungi on plant growth and nutrition in the field. Plant and Soil, The Hague, v.122, p.229-240, 1990a.

DODD, J.C.; ARIAS, I.; KOOMEN, I.; HAYMAN, D.S. The management of populations of vesiculararbuscular mycorrhizal fungi in acid-infertile soils of a savanna ecosystem. II. The effects of pre-cropping on the spore populations of native and introduced VAM-fungi. Plant and Soil, The Hague, v.122, p.241-247, 1990b.

ELLIS, J.R.; RODER, W.; MASON, S.C. Grain sorghumsoybean rotation and fertilization influence on vesicular-arbuscular mycorrhizal fungi. Soil Science Society of America. Journal, Madison, v.56, p.789794, 1992

EVANS, D.G.; MILLER, M.H. The role of the external mycelial network in the effect of soil disturbance upon vesicular-arbuscular mycorrhizal colonization of maize. New Phytologist, Cambridge, v.114, p.6571, 1990.

GERDEMANN. J.W.; NICOLSON, T.H. Spores of mycorrhizal Endogone extracted from soil by wet sieving and decanting. Transactions of the British Mycological Society, Cambridge, v.46, p.235-244, 1963.

GIOVANNETTI, M.; MOSSE, B. An evaluation of techniques for measuring vesicular-arbuscular mycorrhizae infection in roots. New Phytologist, Cambridge, v.84, p.489-500, 1980 .

HARINIKUMAR, K.M.; BAGYARAJ, D.J. Effect of cropping sequence, fertilizers and farmyard manure on vesicular-arbuscular mycorrhizal fungi in different crops over three consecutive seasons. Biology and Fertility of Soils, Berlin, v.7, p.173-175, 1989.

HAYMAN, D.S. Influence of soils and fertility on activity and survival of vesicular-arbuscular mycorrhizal fungi. Phytopathology, St. Paul, v.72, p.1119-1125, 1982.

HAYMAN, D.S. VA mycorrhizas in field crop systems. In: SAFIR, G.R. (Ed.). Ecophysiology of VA mycorrhizal plants. Boca Raton: CRC, 1987. p.171192.

INGLATERRA. Ministry of Agriculture, Fisheries and Food. The analysis of agricultural materials. London: Her Majestys Stationery Office, 1986. 248p.
JANOS, D.P. VA mycorrhizas in humid tropical ecosystems. In: SAFIR, G.R. (Ed.). Ecophysiology of VA mycorrhizal plants. Boca Raton: CRC, 1987. p.107-134

JASPER, D.A.; ABBOTT, L.K.; ROBSON, A.D. Hyphae of a vesicular-arbuscular mycorrhizal fungus maintain infectivity in dry soil, except when the soil is disturbed. New Phytologist, Cambridge, v.112, p.101-107, 1989a

JASPER, D.A.; ABBOTT, L.K.; ROBSON, A.D. Soil disturbance reduces the infectivity of external hyphae of vesicular-arbuscular mycorrhizal fungi. New Phytologist, Cambridge, v.112, p.93-99, 1989b.

JASPER, D.A.; ABBOTT, L.K.; ROBSON, A.D. The effect of soil disturbance on vesicular-arbuscular mycorrhizal fungi in soils from different vegetation types. New Phytologist, Cambridge, v.118, p.471476, 1991

JENKINS, W.R. A rapid centrifugal-flotation technique for separating nematodes from soil. Plant Disease Reporter, St. Paul, v.48, p.692, 1964.

KRUCKELMANN, H.W. Effects of fertilizers, soils, soil tillage, and plant species on the frequency of Endogone chlamydospores and mycorrhizal infection in arable soils. In: SANDERS, F.E.; MOSSE, B.; TINKER, P.B. (Eds.). Endomycorrhizas. London: Academic, 1975. p.511-525.

McGONIGLE, T.P.; EVANS, D.G.; MILLER, M.H. Effect of degree of soil disturbance on mycorrhizal colonization and phosphorus absorption by maize in growth chamber and field experiments. New Phytologist, Cambridge, v.116, p.629-636, 1990.

McGONIGLE, T.P.; MILLER, M.H. Mycorrhizal development and phosphorus absorption in maize under conventional and reduced tillage. Soil Science Society of America. Journal, Madison, v.57, p.10021006, 1993a.

McGONIGLE, T.P.; MILLER, M.H. Responses of mycorrhizae and shoot phosphorus of maize to the frequency and timing of soil disturbance. Mycorrhiza, Berlin, v.4, p.63-68, 1993b.

McGRAW, A.C.; HENDRIX, J.W. Influence of soil fumigation and source of strawberry plants on population densities of spores and infective propagules of endogonaceous mycorrhizal fungi. Plant and Soil, The Hague, v.94, p.425-434, 1986.

OCAMPO, J.A.; HAYMAN, D.S. Influence of plant interactions on vesicular-arbuscular mycorrhizal in- 
fections. II. Crop rotations and residual effects of non-host plants. New Phytologist, Cambridge, v.87, p.333-343, 1981.

O'HALLORAN, I.P.; MILLER, M.H.; ARNOLD, G. Absorption of P by corn (Zea mays L.) as influenced by soil disturbance. Canadian Journal of Soil Science, Ottawa, v.66, p.287-302, 1986.

PHILLIPS, J.M.; HAYMAN, D.S. Improved procedure for clearing roots and staining parasitic and vesicular mycorrhizal fungi for rapid assessment of infection. Transactions of British Mycological Society, Cambridge, v.55, p.158-160, 1970.

SIMPSON, D.; DAFT, M.J. Interactions between waterstress and different mycorrhizal inocula on plant growth and mycorrhizal development in maize and sorghum. Plant and Soil, The Hague, v.121, p.179186,1990

SMITH, S.E. Mycorrhizas of autotrophic higher plants. Biological Reviews, London, v.55, p.475-510, 1980.
STRUBLE, J.E.; SKIPPER, H.D. Vesicular-arbuscular mycorrhizal fungal spore production as influenced by plant species. Plant and Soil, The Hague, v.109, p.277-280, 1988.

THOMPSON, J.P. Decline of vesicular-arbuscular mycorrhizae in long fallow disorder of field crops and its expression in phosphorus deficiency of sunflower. Australian Journal of Agricultural Research, Victoria, v.38, p.847-867, 1987.

TOMMERUP, I.C.; ABBOTT, L.K. Prolonged survival and viability of VA mycorrhizal hyphae after root death. Soil Biology and Biochemistry, Exeter, v.13, p.431-433, 1981.

WHITE, J.W.; IZQUIERDO, J. Physiology of yield potential and stress tolerance. In: SCHOONHOVEN, A.; VOYSEST, O. (Eds.). Common beans - Research for crop improvement. Wallingford: $C A B$ International, 1991. p.287-382. 